\title{
EQUiLIBRIUM
}

Quarterly Journal of Economics and Economic Policy

2014 VOLUME 9 ISSUE 3, September

p-ISSN 1689-765X, e-ISSN 2353-3293

www.economic-policy.pl

Tomczak S. (2014), Comparative Analysis of the Bankrupt Companies of the Sector of Animal Slaughtering and Processing, "Equilibrium. Quarterly Journal of Economics and Economic Policy", Volume 9, Issue 3, pp. 59-86, DOI: http://dx.doi.org/10.12775/EQUIL.2014.018

Sebastian Tomczak ${ }^{*}$

Wroctaw University of Technology, Poland

\section{Comparative Analysis of the Bankrupt Companies of the Sector of Animal Slaughtering and Processing}

\author{
JEL classification: $G 01, G 33, L 66$
}

Keywords: bankruptcy; integrated models; financial ratios

\begin{abstract}
Bankruptcy, especially during an economic crisis, is a common phenomenon. In the adverse changing economic conditions, economic activities become a challenge. Only strong individuals are able to survive the economic fluctuations, while others are eliminated from the market. The integrated models are used in predicting bankruptcy. These models are often designed on the basis of financial indicators. Some of these models use similar financial indicators, in many cases using the same ones. The present study deals with the evaluation of the sector of animal slaughtering and processing in the period 2000-2011, as well as the evaluation of the causes of business failure in the sector, and the comparison of bankrupt companies in the sector.
\end{abstract}

\section{Introduction}

Operation of enterprises in the conditions of increasing competition in the market involves uncertainty regarding "intentional" success. Furthermore, the current period of economic downturn forces continuous changes in the business, and it causes companies to be more flexible in relation to the

(C) Copyright Institute of Economic Research \& Polish Economic Society Branch in Toruń

Date of submission: April 12, 2013; date of acceptance: March 8, 2014

* Contact: sebastian.tomczak@pwr.edu.pl, Wrocław University of Technology, Wybrzeże Wyspiańskiego 27, 50-370 Wrocław, Poland 
newly created market conditions and competition.

The prediction of changes in the company constructed various types of integrated models. These models are designed to evaluate the company as a whole - it is called integrated financial analysis. Using these models, a company is classified into one of the specified categories. Models of discriminant analysis are the most frequently used (Korol, 2010, p. 96).

Altman, was a pioneer of inventing of discriminant analysis to predict the bankruptcy of individuals, who presented in 1968 a synthetic model consisting of five financial ratios (Altman, 1993, p. 186). In Poland, the first similar models were constructed in the 90's of the twentieth century, after the economic transformation. Mączyńska is considered as one of the most famous Polish researchers in the bankruptcy of individuals and their forecasting. She has created many models of discrimination (Mączyńska, 1994, pp. 42-43; Mączyńska \& Zawadzki, 2006, pp. 205-234). In addition to the proposed models of Mączyńska, many other authors of Polish models can be presented, namely: Appenzeller and Szarzec (2004, pp. 120-128); Gajdka and Stos (1996a, pp. 138-147; 1996b, pp. 56-65); Hadasik (1998, pp. 133-175); Hamrol (2004, pp. 35-39); Hołda (2007, pp. 306-310); Prusak (2005, pp. 131); Pogodzińska and Sojak (1995, pp. 53-61); Prusak (2005, pp. 92-123). It should be emphasized that the Polish models are better in predicting financial condition of the companies in Polish economy than overseas models (Tomczak, 2009, pp. 161-166; Tomczak, 2010, pp. 91-101).

Integrated models are usually constructed on the basis of financial indicators. The basis source for many of these models are similar financial ratios, in many cases they are the same. Therefore, an analysis of 47 models and 34 integrated models allowed to select 13 most common indicators in these models. The selected indicators come from different groups: four ratios of the turnover, three indicators of liquidity, profitability and debt. It should be noticed, that some of selected indicators have predictive features. These distinguishing marks were observed by Tomczak and Górski (2011, pp. 159-168); Tomczak (2012, pp. 203-208), Tomczak and Górski (2012, pp. 208-226) in the study of the approaching insolvency of analyzed groups of companies.

Conducted research that basically came down to calculating values of particular financial indicators was based on simplified financial reports of companies, which was taken from Emerging Markets Information Service (EMIS). In this database one can find the most important information regarding markets and companies. 
The purpose of this article is evaluation of the sector of animal slaughtering and processing in the years 2000-2011. The average values and median of the most common financial ratios models were assessed. The calculation of average values of selected indicators will provide benchmarks for the trade. This calculations enable an evaluation of the sample of selected bankrupt companies, which indicate the cause of their failure. The study used the following methods:

- Studying literature.

- Case Studies.

- The study on the example of financial indicators of companies from the sector of animal slaughtering and processing.

\section{Methodology of research}

There are many causes of business failure. The article focuses on the identification of the causes of the financial bankruptcy of companies, on the basis of financial analysis. In literature there are many illustrated integrated models, as mentioned above, although in practice they are not used. So the companies do not use them to monitor their financial condition. The author wanted to demonstrate financial reasons for business failure by analyzing financial ratios.

First, models were analyzed in terms of repeatability of indicators. Then those that occurred most frequently in models were selected. Next, values of selected indicators for a sample of 395 companies were calculated.

Each industry is characterized by different characteristics, even when food production as a whole is analyzed. Financial ratios can have different values than the chosen sector of animal slaughtering and processing (Tomczak, 2013, pp. 409-423). The author considers these values of ratios as a standard value for the industry. The accepted reference of value ratios were compared with the values of the calculated indicators for bankrupt companies. This made it possible to demonstrate which financial indicators signaled an impending bankruptcy.

\section{Selection of the companies}

Ten bankrupt companies of the sector of animal slaughtering and processing was selected for the analysis. Selected bankrupt companies are presented in Table 1. 
Table 1. Selected bankrupt companies

\begin{tabular}{|c|c|c|c|c|}
\hline $\mathbf{N r}$ & Name of the bankrupt company & Founded & $\begin{array}{c}\text { The } \\
\text { period of } \\
\text { study }\end{array}$ & $\begin{array}{c}\text { Size } \\
\text { [in ths. } \mathbf{z l}]\end{array}$ \\
\hline 1. & BARTA & 1990 & 2011 & 166,76 \\
\hline 2. & $\begin{array}{c}\text { KROTOSZYNSKA SPÓŁDZIELNIA } \\
\text { PRODUCENTÓW WOŁOWINY }\end{array}$ & 2005 & 2010 & 545,27 \\
\hline 3. & PMB Białystok S.A. & 1962 & 2011 & 974,65 \\
\hline 4. & RPM J. I P. GAWŁOWSKI S.C. & 1990 & 2009 & 6175,54 \\
\hline 5. & SPÓŁDZIELNIA DOBROSŁAWA & 1945 & 2010 & 8495,21 \\
\hline 6. & UBOJNIA DOBROSŁAWA SP. Z O.O. & 2001 & 2010 & 12693,86 \\
\hline 7. & WIR EURO UBOJNIA & 2004 & 2011 & 15323,38 \\
\hline 8. & ZAKŁAD WĘDLINIARSKI MARY- & & & \\
\hline 9. & ZM MAT CZERNIEWICE SP. Z O.O. & 2000 & 2010 & 54859,54 \\
\hline 10. & ZPM IZABELA I ZBIGNIEW GRA- & 1996 & 2010 & 92623,81 \\
\hline
\end{tabular}

Source: own work.

In addition to the analysis of indicators of the bankrupt companies, in the paper an evaluation of the sector of animal slaughtering and processing is carried out. The calculation of average (mean) value of each financial indicators provides benchmarks for the assessing of the companies involved in the industry.

Thirty-four integrated models (mostly of Polish authorship) were analyzed, under which a group of 13 most commonly used financial ratios was selected. This group of financial indicators was used to evaluate companies. Selected indicators come from the different groups: four ratios of the turnover, three indicators of liquidity, profitability and debt. Table 2 presents selected financial ratios - starting with those that are the most common in integrated models. Due to the volume restrictions on the article, further information of integrated models can be found in (Altman \& Hotchkiss, 2006, pp. 233-264; Prusak (ed.), 2007; pp. 162-176; Zaleska, 2002, pp. $23-$ $50)$. 
Table 2. Selected financial ratios

\begin{tabular}{|l|}
\hline current liquidity ratio, \\
\hline total asset turnover, \\
\hline total debts to assets, \\
\hline ROI, \\
\hline inventory turnover, \\
\hline equity to assets, \\
\hline net profit + depreciation to total liabilities, \\
\hline the size of the working capital ratio (1), \\
\hline ROA, \\
\hline gross profitability, \\
\hline the size of the working capital ratio (2), \\
\hline accounts receivable turnover, \\
\hline revenue growth. \\
\hline
\end{tabular}

Source: own work.

It is worth to notice that some of the selected indicators have a predictive features:

- current liquidity ratio,

- net profit + depreciation to total liabilities,

- ROI,

- equity to assets,

- the size of the working capital ratio (1),

- ROA,

- the size of the working capital ratio (2).

The low values of these indicators may suggest a deterioration of the financial condition of the company, which could consequently lead to bankruptcy (Tomczak, 2012, p. 206).

\section{Analysis of selected companies of the sector of animal slaughtering and processing}

395 companies from the sector were analyzed. Mean values of selected indicators, median and standard deviation were calculated on the basis of companies' financial statements. The summarized results of the research are presented in charts 1-13. The summarized results were used as a model to 
try to assess the causes of the bankruptcy of selected sample. Due to the lack of access to the financial statements for the one year prior to bankruptcy, the tested sample included only 10 companies.

Due to the limits of the article, the following indicators are not included in the detailed analysis:

- equity to assets, for which the average (mean) fluctuates $38-50 \%$, while the median is in the range of $37-46 \%$,

- the size of the working capital ratio (2), for the average (mean) fluctuates $0,02-0,50$, while the median is in the range of -0.04-0.09.

The first analyzed indicator is current liquidity ratio (see Figure 1). According to the literature, the value of this ratio should fluctuate between 1.2-2.0 (Walczak (ed.), 2007, pp. 356-357). However, for each sector, the optimum value of this ratio can vary.

Figure 1. The values of the current liquidity ratio during 2000-2011

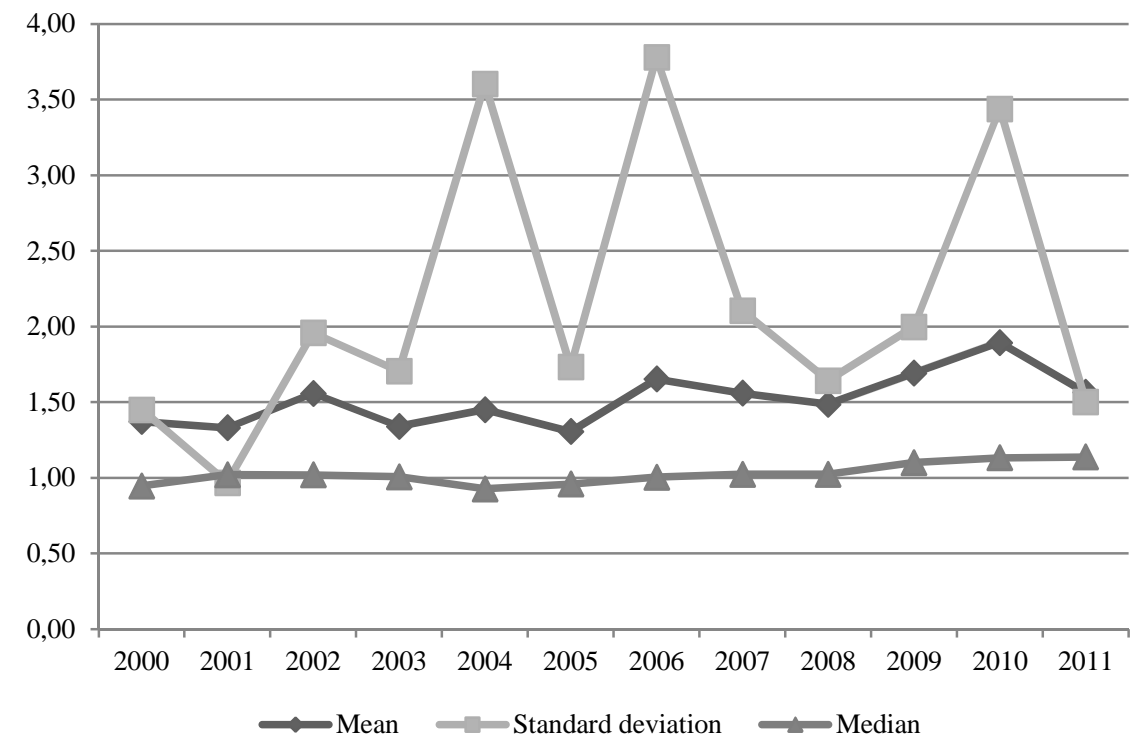

Source: own work.

Analyzing the first indicator, it can be said that the average value of the current liquidity ratio for the period 2000-2011 oscillates between 1,311,89 . However, the median value is significantly lower and fluctuates in the range of $0,93-1,14$. The mean value of this ratio is comparable to the preferred values given in the literature. However, it should be noted that devia- 
tions from the mean for some years is significant, which may affect the misinterpretation, therefore more appropriate measure in this case is the median.

Table 3. The values of the current liquidity ratio of the selected sample

\begin{tabular}{|l|c|}
\hline Name of the bankrupt company & CA/STL \\
\hline BARTA & 56,10 \\
\hline KROTOSZYŃSKA SPÓŁDZIELNIA PRODUCENTÓW WOŁOWINY & 1,15 \\
\hline PMB Białystok S.A. & 0,55 \\
\hline RPM J. I P. GAWŁOWSKI S.C. & 0,86 \\
\hline SPÓŁDZIELNIA DOBROSŁAWA & 0,66 \\
\hline UBOJNIA DOBROSŁAWA SP. Z O.O. & 0,37 \\
\hline WIR EURO UBOJNIA & 0,71 \\
\hline $\begin{array}{l}\text { ZAKŁAD WĘDLINIARSKI MARYMUD MARIAN I RYSZARD MU- } \\
\text { DZO }\end{array}$ & 5,08 \\
\hline ZM MAT CZERNIEWICE SP. Z O.O. & 1,17 \\
\hline ZPM IZABELA I ZBIGNIEW GRABOWSCY S.J. & 0,91 \\
\hline
\end{tabular}

Source: own work.

Among the bankrupt companies presented in Table 3, the company Bart for the year before the bankruptcy was characterized by the highest value of test ratio -56.10 . This high value indicates overliquidity - a big freeze of funds in current assets. Zakład Wędliniarski also is characterized by excess liquidity. Other failed companies are characterized by low liquidity, or the lack of it. Lack of liquidity appeared in such companies as PMB, Spółdzielnia Dobrosława, Ubojnia czy Wir Euro. Note that this indicator has the predictive features, therefore low values of this ratio can contribute to the bankruptcy.

The second indicator is total asset turnover (see Figure 2). Using this pointer, one can examine the value of sales attributable to the assets. The positive trend is considered to increase the value of this indicator.

According to literature, the value of this ratio should oscillate between 0.5 and 1.5. The interpretation of these values is representative of the return on capital, expressed in PLN (Kowalak, 2008, p. 151). 
Figure 2. The values of total asset turnover during 2000-2011

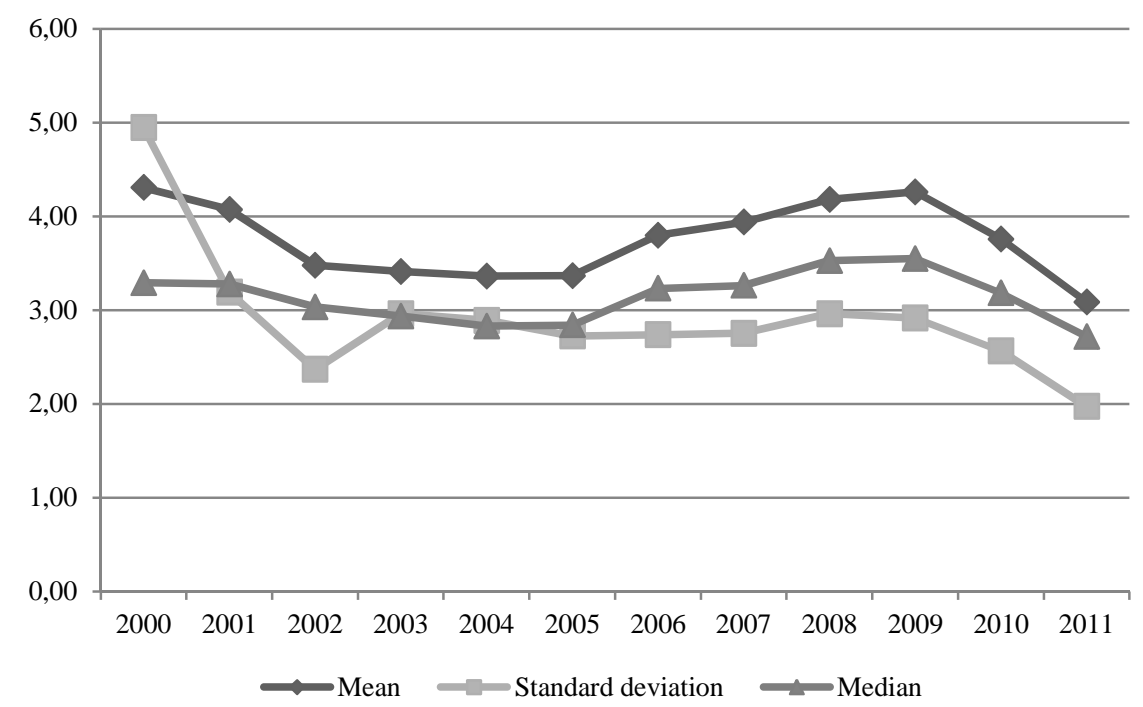

Source: own work.

During the analyzed period, the average value of the asset turnover ratio fluctuates in the range of 3,09-4,31. However, the median value is slightly lower and oscillates in the range of 2,72-3,35. The average value of this indicator is higher than the preferred values given in the literature, which results in a higher rate of return on capital, expressed in PLN. However, since 2009, was a decrease in the value of the indicator, which translates to reduced returns. At the end of the period, the value of the indicator was 3.09 , which means that 1 PLN equity in a company engaged in the business will bring 3.09 PLN net sales of products.

The two companies that closed down during the period (Table 4), were characterized by a very high rate of return on capital, because the values of this ratio for the company Krotoszyńska Spółdzielnia and RPM are higher than the industry average. It is worth noting that the Krotoszyńska Spódzielnia sold out all fixed assets in order to pay some part of the liabilities, so the value of the indicator is high. Other bankrupt companies have a much lower value of the index. Bart company reached the lowest value of indicator close to zero. 
Table 4. The values of total asset turnover of the selected sample

\begin{tabular}{|l|c|}
\hline Name of the bankrupt company & SR/TA \\
\hline BARTA & 0,01 \\
\hline KROTOSZYŃSKA SPÓŁDZIELNIA PRODUCENTÓW WOŁOWINY & 15,45 \\
\hline PMB Białystok S.A. & 2,79 \\
\hline RPM J. I P. GAWŁOWSKI S.C. & 4,49 \\
\hline SPÓŁDZIELNIA DOBROSŁAWA & 1,75 \\
\hline UBOJNIA DOBROSŁAWA SP. Z O.O. & 1,90 \\
\hline WIR EURO UBOJNIA & 1,51 \\
\hline $\begin{array}{l}\text { ZAKŁAD WĘDLINIARSKI MARYMUD MARIAN I RYSZARD } \\
\text { MUDZO }\end{array}$ & 2,76 \\
\hline ZM MAT CZERNIEWICE SP. Z O.O. & 1,68 \\
\hline ZPM IZABELA I ZBIGNIEW GRABOWSCY S.J. & 3,12 \\
\hline
\end{tabular}

Source: own work.

Another indicator is considered total debts to assets (see Figure 3). This ratio determines the amount of the liabilities (foreign capital) to the assets of the company. The benchmark value of this ratio oscillates according to western standards in the range of 57-64\%. However, too high a value of indicator signals a high financial risk, it is information for managers of the prospect of losing the ability to repay liabilities (Ćwiąkała-Małys \& Nowak, 2005, p. 121).

Based on the above chart, it can be concluded that during the period the company used less and less of foreign capital. The reason may be increased restrictions associated with obtaining credits or desire autonomy of the business from lenders, which especially in times of crisis is a positive development. 
Figure 3. The values of total debts to assets during 2000-2011

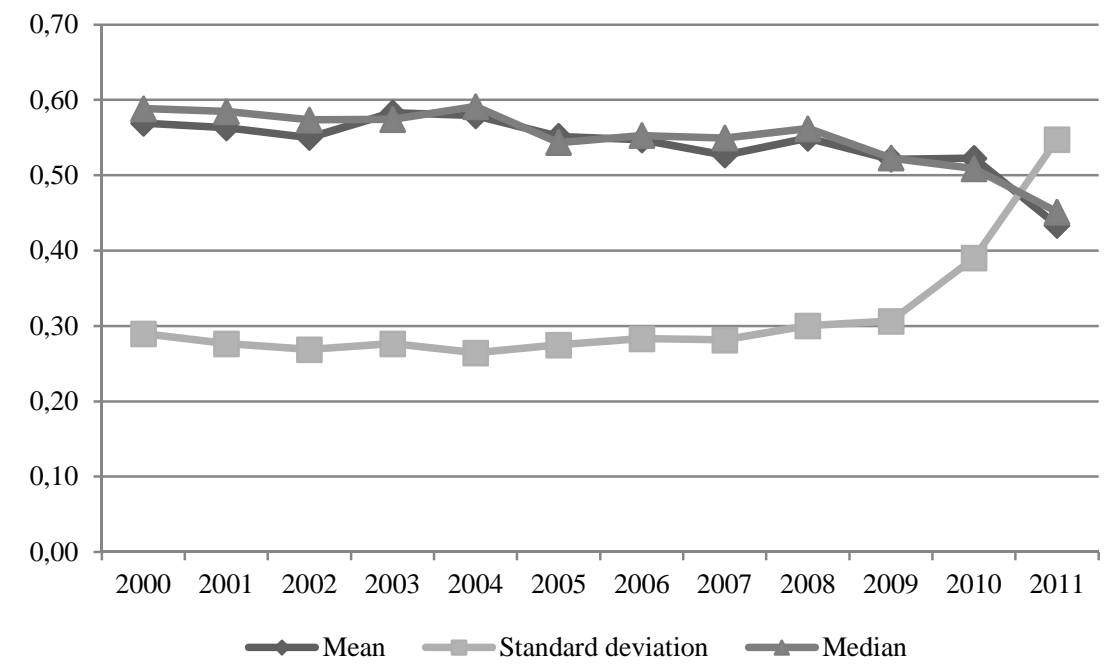

Source: own work.

Table 5. The values of total debts to assets of the selected sample

\begin{tabular}{|l|c|}
\hline Name of the bankrupt company & TD/TA \\
\hline BARTA & 0,02 \\
\hline KROTOSZYŃSKA SPÓŁDZIELNIA PRODUCENTÓW WOŁOWINY & 0,87 \\
\hline PMB Białystok S.A. & 1,02 \\
\hline RPM J. I P. GAWŁOWSKI S.C. & 0,71 \\
\hline SPÓŁDZIELNIA DOBROSŁAWA & 0,26 \\
\hline UBOJNIA DOBROSŁAWA SP. Z O.O. & 0,41 \\
\hline WIR EURO UBOJNIA & 0,65 \\
\hline $\begin{array}{l}\text { ZAKŁAD WĘDLINIARSKI MARYMUD MARIAN I RYSZARD } \\
\text { MUDZO }\end{array}$ & 0,10 \\
\hline ZM MAT CZERNIEWICE SP. Z O.O. & 0,60 \\
\hline ZPM IZABELA I ZBIGNIEW GRABOWSCY S.J. & 0,61 \\
\hline
\end{tabular}

Source: own work. 
Six of ten companies listed in Table 5 was characterized by a very high share of foreign capital. Especially in times of crisis can lead to tragic consequences, as a too high share of foreign capital leads to abnormal dependence on the lender, which translates into a very high cost of foreign capital and higher financial risk. These companies are Krotoszyńska Spółdzielnia, PMB, RPM, WIR, ZM MAT and ZPM. Other bankrupt companies are characterized by a lower share of foreign capital.

The next indicator is considered to be net profit + depreciation to the total liabilities which is also sometimes called the indicator of credit (see Figure 4). The value of ratio specifies the coverage of total liabilities with financial surplus generated by the company. The increase in the value of this indicator is considered to be a positive development, it means a reduction in the time it takes us to repay (Zaleska, 2012, p. 89).

Figure 4. The values of net profit + depreciation to total liabilities during 20002011

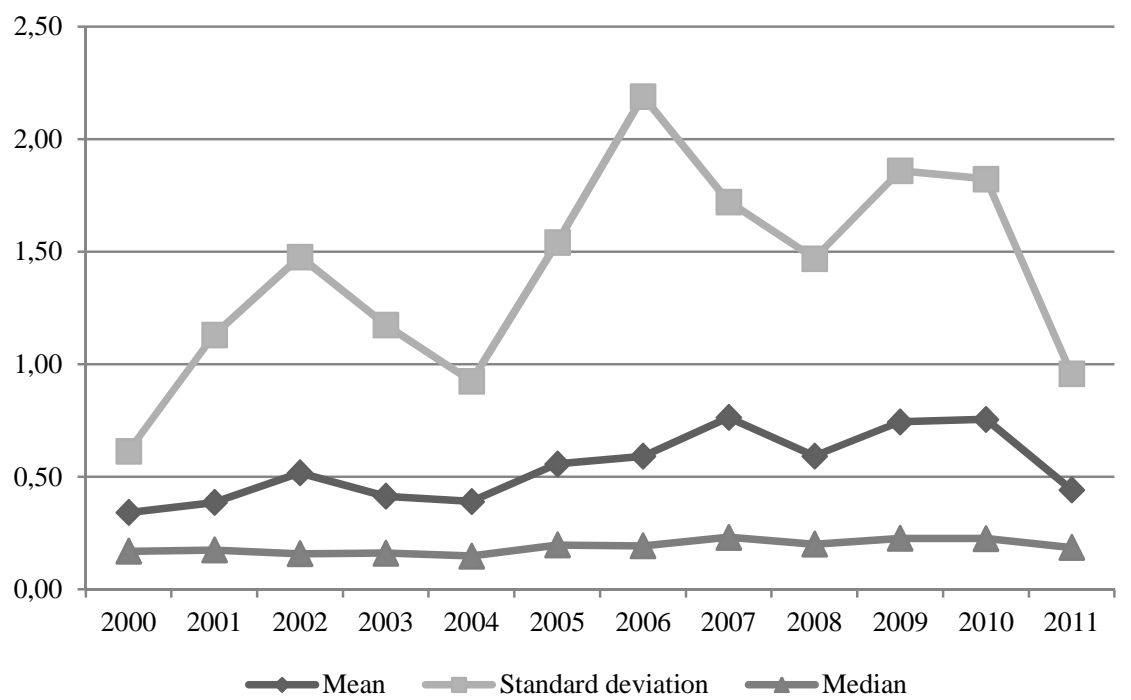

Source: own work.

Average value of the indicator fluctuates in the range of $0,34-0,76$, while the median value is lower and oscillates in the range of $0,15-0,23$. During the study period, a slight upward trend can be seen, not including last year, which may mean a reduction of the time required by the company to pay off liabilities. Especially during a crisis, it is a preferred phenome- 
non. It should be noted that the deviations of mean is large, therefore a more appropriate measure of assessment is the median.

Table 6. The values of net profit + depreciation to total liabilities of the selected sample

\begin{tabular}{|l|c|}
\hline Name of the bankrupt company & NP+D/TL \\
\hline BARTA & $-29,66$ \\
\hline $\begin{array}{l}\text { KROTOSZYŃSKA SPÓŁDZIELNIA PRODUCENTÓW WOŁOWI- } \\
\text { NY }\end{array}$ & 0,23 \\
\hline PMB Białystok S.A. & $-0,19$ \\
\hline RPM J. I P. GAWŁOWSKI S.C. & 0,13 \\
\hline SPÓŁDZIELNIA DOBROSŁAWA & $-0,07$ \\
\hline UBOJNIA DOBROSŁAWA SP. Z O.O. & $-0,41$ \\
\hline WIR EURO UBOJNIA & $-0,11$ \\
\hline $\begin{array}{l}\text { ZAKŁAD WĘDLINIARSKI MARYMUD MARIAN I RYSZARD } \\
\text { MUDZO }\end{array}$ & $-0,29$ \\
\hline ZM MAT CZERNIEWICE SP. Z O.O. & 0,06 \\
\hline ZPM IZABELA I ZBIGNIEW GRABOWSCY S.J. & 0,08 \\
\hline
\end{tabular}

Source: own work.

Out of ten tested companies, six were characterized by a negative value of the indicator. Those companies are Barta, PMB, Spółdzielnia Dobrosława, Ubojnia, Wir, Zakład Wędliniarski. Negative values of this ratio indicate a negative phenomenon - the lack of ability to generate profits for the company and thus the loss of ability to repay their liabilities. For other companies this ratio is higher than zero. On the basis of the negative value of the indicator one can infer about the probability of bankruptcy of a company.

Another indicator is considered to be inventory turnover ratio (see Figure 5). The ratio of inventory turnover indicates the number of days during which the company renews its inventory. A too high a level of indicator (low inventory turns per year) is judged negatively because it demonstrates the involvement of larger stocks, by freezing more cash. It means that the company has managed its inventory very poorly (Dudycz et al. 2005, p. 3). 
Figure 5. The values of inventory turnover during 2000-2011

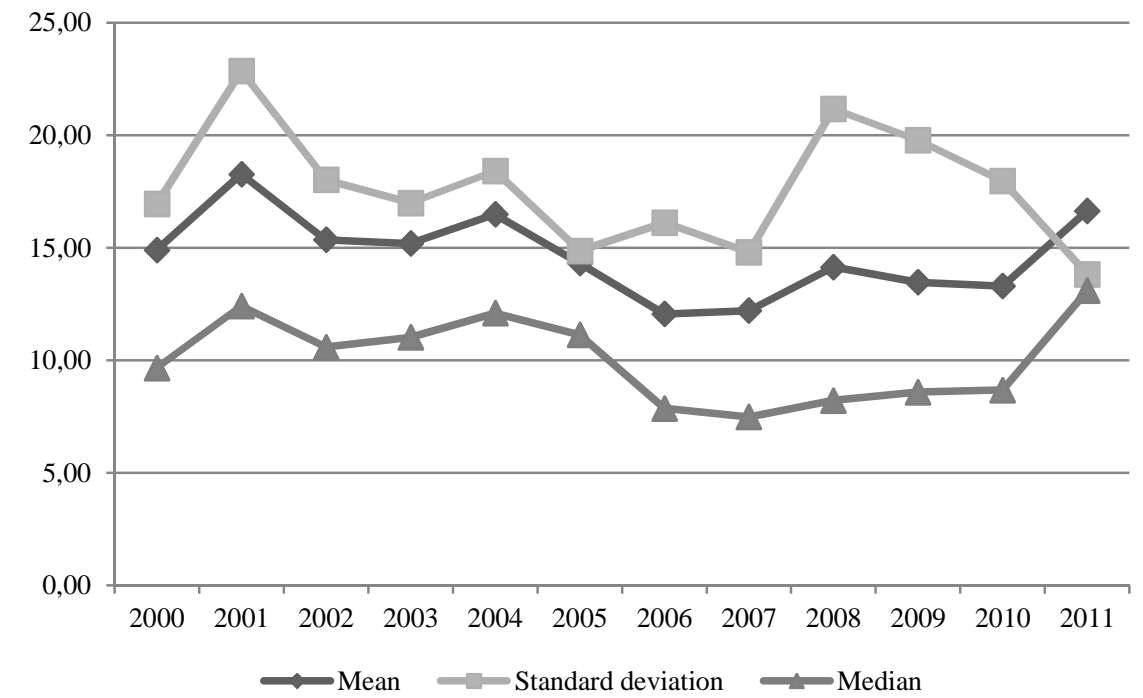

Source: own work.

The values of the analyzed indicator - inventory turnover values are strictly related to the nature of the business. In this industry, maintenance of a stock at the right level is crucial. Basing on the analysis of the chart, it is found that the value of the indicator oscillates between 12-17 days. However, the median value is lower and fluctuates in the range of 7-12 days. During the period every 15 days followed stocks turnover.

Table 7. The values of inventory turnover of the selected sample

\begin{tabular}{|l|c|}
\hline Name of the bankrupt company & I/SR \\
\hline BARTA & 102,71 \\
\hline KROTOSZYŃSKA SPÓŁDZIELNIA PRODUCENTÓW WOŁOWINY & 0,00 \\
\hline PMB Białystok S.A. & 13,15 \\
\hline RPM J. I P. GAWŁOWSKI S.C. & 29,57 \\
\hline SPÓŁDZIELNIA DOBROSŁAWA & 6,84 \\
\hline UBOJNIA DOBROSŁAWA SP. Z O.O. & 4,47 \\
\hline
\end{tabular}


Table 7 Continued

\begin{tabular}{|l|c|}
\hline Name of the bankrupt company & I/SR \\
\hline WIR EURO UBOJNIA & 12,24 \\
\hline $\begin{array}{l}\text { ZAKŁAD WĘDLINIARSKI MARYMUD MARIAN I RYSZARD } \\
\text { MUDZO }\end{array}$ & 8,19 \\
\hline ZM MAT CZERNIEWICE SP. Z O.O. & 27,09 \\
\hline ZPM IZABELA I ZBIGNIEW GRABOWSCY S.J. & 15,85 \\
\hline
\end{tabular}

Source: own work.

Three companies of the analyzed group have higher inventory turnover than the industry average. Those companies are Barta, PMB, RPM. An important role in this sector is played by a proper turnover stocks, because food supplies have validity term for consumption. Stocks are excluded from trade beyond the expiry date, which generates costs. It is worth mentioning that Krotoszyńska Spółdzielnia did not have any stock, so the value of the indicator is equal to zero.

The sixth indicator is the rate of return on investment - ROI return (see Figure 6). Return on investment determines the level of operating profitability of the company, which is the core business for which company was "brought to life". Return on ROI can determine the ability of assets to generate profit, no matter how they are financed (Skowrońska-Mielczarek \& Leszczynski, 2007, p. 160).

Figure 6. The values of ROI during 2000-2011

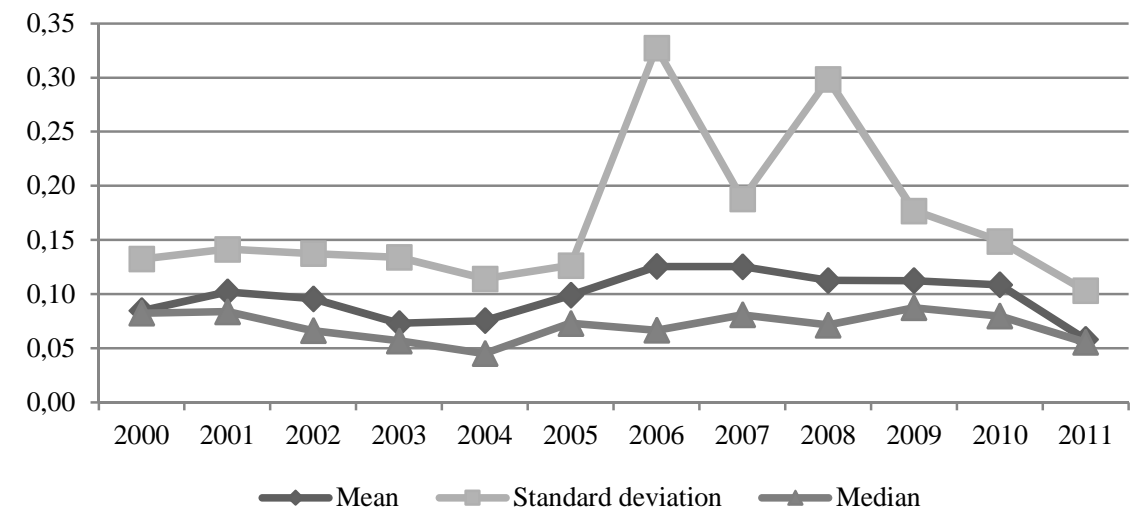

Source: own work. 
During the period companies generate an operating profit between 6$13 \%$. However, the median value is slightly lower and oscillates between 5$9 \%$. The mean value of this ratio is high, which could mean that the industry was well during the period, bringing profits.

Table 8. The values of ROI of the selected sample

\begin{tabular}{|l|c|}
\hline Name of the bankrupt company & OP / TA \\
\hline BARTA & $-0,07$ \\
\hline KROTOSZYŃSKA SPÓŁDZIELNIA PRODUCENTÓW WOŁOWINY & 0,27 \\
\hline PMB Białystok S.A. & 0,00 \\
\hline RPM J. I P. GAWŁOWSKI S.C. & 0,11 \\
\hline SPÓŁDZIELNIA DOBROSŁAWA & $-0,03$ \\
\hline UBOJNIA DOBROSŁAWA SP. Z O.O. & $-0,22$ \\
\hline WIR EURO UBOJNIA & $-0,12$ \\
\hline $\begin{array}{l}\text { ZAKŁAD WĘDLINIARSKI MARYMUD MARIAN I RYSZARD } \\
\text { MUDZO }\end{array}$ & $-0,06$ \\
\hline ZM MAT CZERNIEWICE SP. Z O.O. & 0,04 \\
\hline ZPM IZABELA I ZBIGNIEW GRABOWSCY S.J. & 0,00 \\
\hline
\end{tabular}

Source: own work.

Seven companies were characterized by a negative value of the ratio. The companies are Barta, PMB, Spółdzielnia Dobrosława, Ubojnia, Wir, Zakład Wędliniarski oraz ZPM. This is bad, because negative values indicate that the company generates a loss from the core activities for which it has been "brought to life". Note that this indicator has the predictive characteristics, therefore low values of this ratio can contribute to the failure.

Seventh indicator is the size of the working capital ratio (see Figure 7). It is assumed that a high level of working capital ratio means great involvement of working capital in the total assets, as well as high liquidity of the company. However, it should be noted that the degree of wear and tear of fixed assets influences the size of ratio. The indicator value is relatively high, when a firm has a low level of fixed assets or a significant degree of wear. In this case, it will not mean a favorable situation of the company (Kusak, 2006, pp. 46-47). 
Figure 7. The values of the size of the working capital ratio (1) during 2000-2011

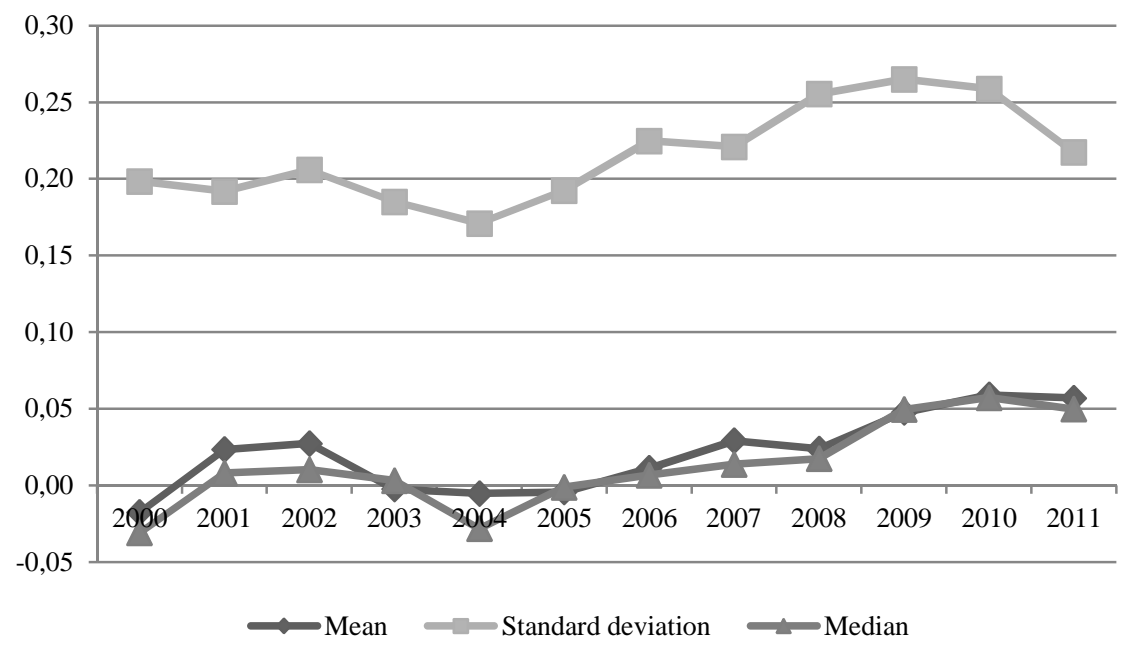

Source: own work.

The indicator of working capital during the period fluctuates between $-0.02-0.06$. However, the median value oscillates around the $-0.03-0.19$. The values of the tested ratio increase since 2004. This could mean that the involvement of working capital in the total assets increased, which is a good thing.

Table 9. The values of the size of the working capital ratio (1) of the selected sample

\begin{tabular}{|l|c|}
\hline Name of the bankrupt company & WC / TA \\
\hline BARTA & 0,98 \\
\hline KROTOSZYŃSKA SPÓŁDZIELNIA PRODUCENTÓW WOŁOWINY & 0,13 \\
\hline PMB Białystok S.A. & $-0,26$ \\
\hline RPM J. I P. GAWŁOWSKI S.C. & $-0,09$ \\
\hline SPÓŁDZIELNIA DOBROSŁAWA & $-0,09$ \\
\hline UBOJNIA DOBROSŁAWA SP. Z O.O. & $-0,21$ \\
\hline WIR EURO UBOJNIA & $-0,14$ \\
\hline
\end{tabular}


Table 9 Continued

\begin{tabular}{|l|c|}
\hline Name of the bankrupt company & WC / TA \\
\hline $\begin{array}{l}\text { ZAKŁAD WĘDLINIARSKI MARYMUD MARIAN I RYSZARD } \\
\text { MUDZO }\end{array}$ & 0,42 \\
\hline ZM MAT CZERNIEWICE SP. Z O.O. & 0,04 \\
\hline ZPM IZABELA I ZBIGNIEW GRABOWSCY S.J. & $-0,03$ \\
\hline
\end{tabular}

Source: own work.

Among the ten companies, six of them have a negative value of the index. This is considered negative phenomenon, because it means that the involvement of working capital in the total assets is practically none, denotes low liquidity as well. Those companies are PMB, RPM, Spółdzielnia Dobrosława, Ubojnia, Wir oraz ZPM. Other failed companies are characterized by positive values of the index.

Eighth, in turn, the indicator of the profitability of assets ROA ratio is considered (see Figure 8). This indicator shows the efficiency of the business assets. In addition, it also determines the ability of the business assets to generate profits. Benchmark value fluctuates in the range of 2 to $6 \%$. The authors of (Iwanicz-Drozdowska, 2005, pp. 69-73) show that the value of this ratio should be higher for small businesses than for big.

Figure 8. The values of ROA during 2000-2011

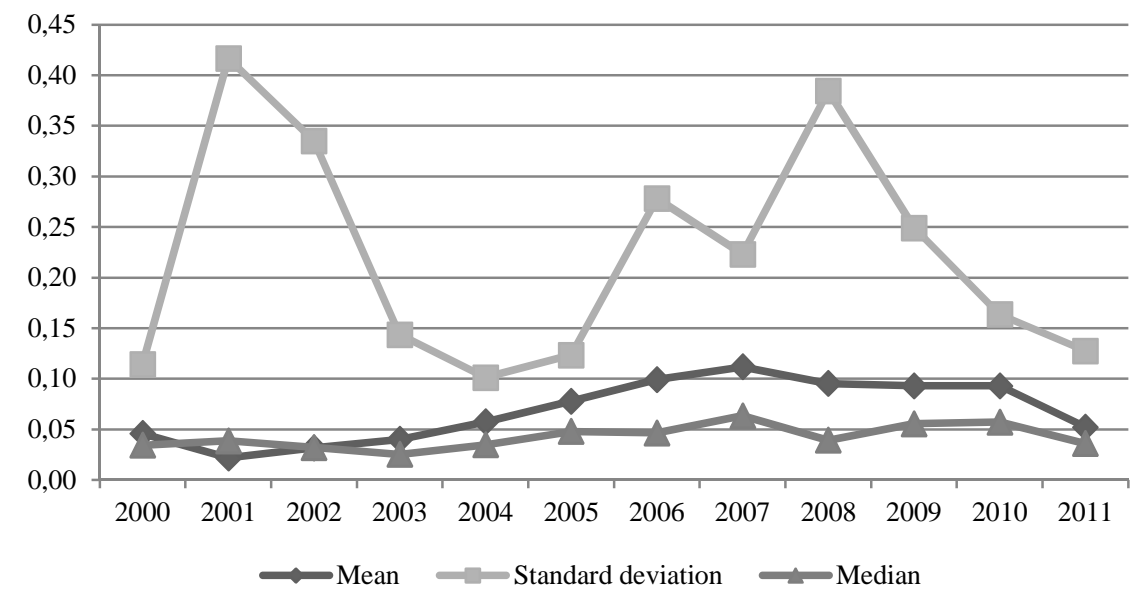

Source: own work. 
In the analyzed period, the average value of the indicator of profitability fluctuates between $2-11 \%$. However, the median value is lower and oscillates in the range of $3-6 \%$. The mean value of this ratio is higher than the preferred values quoted in the literature, which means that companies in the industry manage their assets efficiently.

Table 10. The values of ROA of the selected sample

\begin{tabular}{|l|c|}
\hline Name of the bankrupt company & NP / TA \\
\hline BARTA & $-0,53$ \\
\hline KROTOSZYŃSKA SPÓŁDZIELNIA PRODUCENTÓW WOŁOWINY & 0,19 \\
\hline PMB Białystok S.A. & $-0,23$ \\
\hline RPM J. I P. GAWŁOWSKI S.C. & 0,05 \\
\hline SPÓŁDZIELNIA DOBROSŁAWA & $-0,04$ \\
\hline UBOJNIA DOBROSŁAWA SP. Z O.O. & $-0,23$ \\
\hline WIR EURO UBOJNIA & $-0,13$ \\
\hline ZAKŁAD WĘDLINIARSKI MARYMUD MARIAN I RYSZARD & \\
MUDZO & $-0,06$ \\
\hline ZM MAT CZERNIEWICE SP. Z O.O. & 0,01 \\
\hline ZPM IZABELA I ZBIGNIEW GRABOWSCY S.J. & $-0,03$ \\
\hline
\end{tabular}

Source: own work.

The conducted analyses indicate that companies which are characterized by a negative value of assets profitability ratio also have an operating loss.

The ninth indicator considered is the receivables turnover ratio (see Figure 9). The indicator of receivables turnover ratio means the average number of days within which payment from customers is due. A high level of this ratio indicates inefficient revenue collection policy, which is unfavorable for the company, as it means greater involvement of capital in the circulation. High levels may indicate the presence of hard recoverable receivables, uncollectible in the future (Mohr, 2006, pp. 48-52). 
Figure 9. The values of accounts receivable turnover during 2000-2011

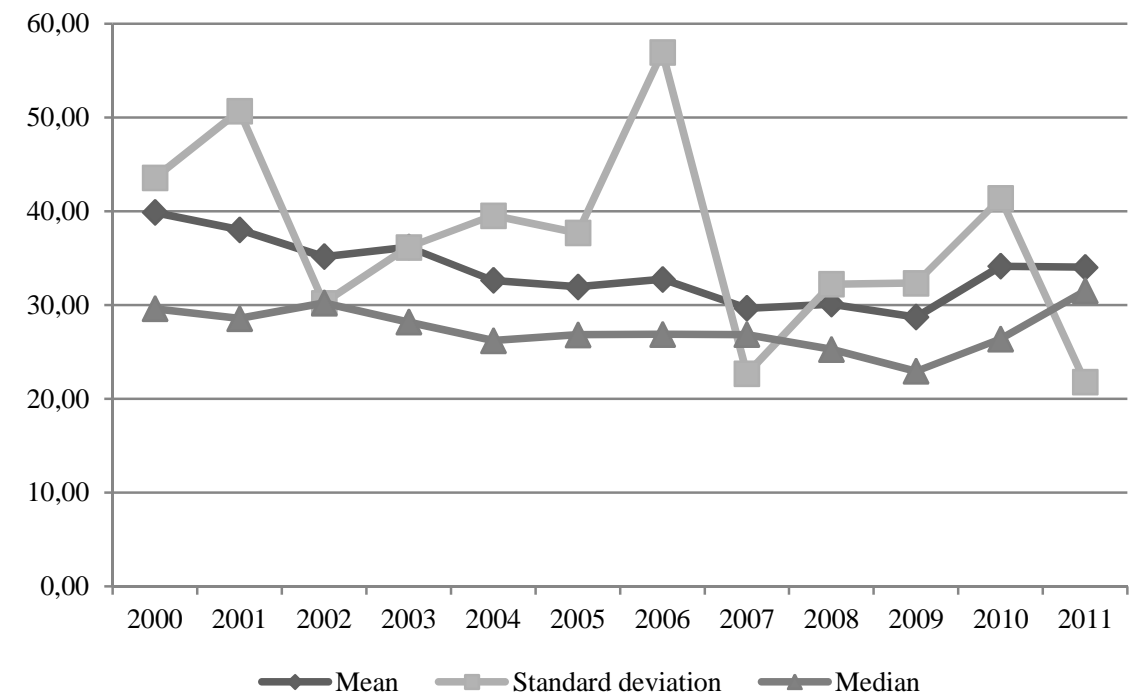

Source: own work.

The average value of the receivables turnover ratio during the period oscillates in the range of 29-40 days, whereas, the median value is lower and fluctuates between 23-32 days. In this period there is a downward trend in the value of the indicator with the exception of the last two years. This is beneficial for companies in the industry, because they recover the their receivables more effectively. The average period of receivables collection was 34 days.

Table 11. The values of accounts receivable turnover of the selected sample

\begin{tabular}{|l|c|}
\hline Name of the bankrupt company & R /SR \\
\hline BARTA & 522,74 \\
\hline KROTOSZYŃSKA SPÓŁDZIELNIA PRODUCENTÓW WOŁOWINY & 12,80 \\
\hline PMB Białystok S.A. & 23,71 \\
\hline RPM J. I P. GAWŁOWSKI S.C. & 11,06 \\
\hline SPÓŁDZIELNIA DOBROSŁAWA & 25,90 \\
\hline UBOJNIA DOBROSŁAWA SP. Z O.O. & 18,21 \\
\hline
\end{tabular}


Table 11 Continued

\begin{tabular}{|l|c|}
\hline Name of the bankrupt company & R /SR \\
\hline WIR EURO UBOJNIA & 67,29 \\
\hline $\begin{array}{l}\text { ZAKŁAD WĘDLINIARSKI MARYMUD MARIAN I RYSZARD } \\
\text { MUDZO }\end{array}$ & 58,80 \\
\hline ZM MAT CZERNIEWICE SP. Z O.O. & 29,36 \\
\hline ZPM IZABELA I ZBIGNIEW GRABOWSCY S.J. & 13,45 \\
\hline
\end{tabular}

Source: own work.

The listed companies didn't have control of debt collection. Improper debt collection can lead to bankruptcy. The three companies have a much higher ratio than the preferred value of the industry, which are Barta, WIR and Zakład Wędliniarski.

Tenth, in turn, the indicator of the gross profitability ratio before tax is considered (see Figure 10). Gross profitability indicator shows the combined financial effect of pre-tax, resulting from all the company's activities in relation to sales revenues. Includes gross margin obtained from operating activities, the costs of the enterprise, the cost of sales, as well as the effects of the financial operations and extraordinary results. This indicator shows the complete picture of the company achieved sales performance before tax (Kowalczyk \& Kusak, 2006, pp. 4-5).

Figure 10. The values of gross profitability during 2000-2011

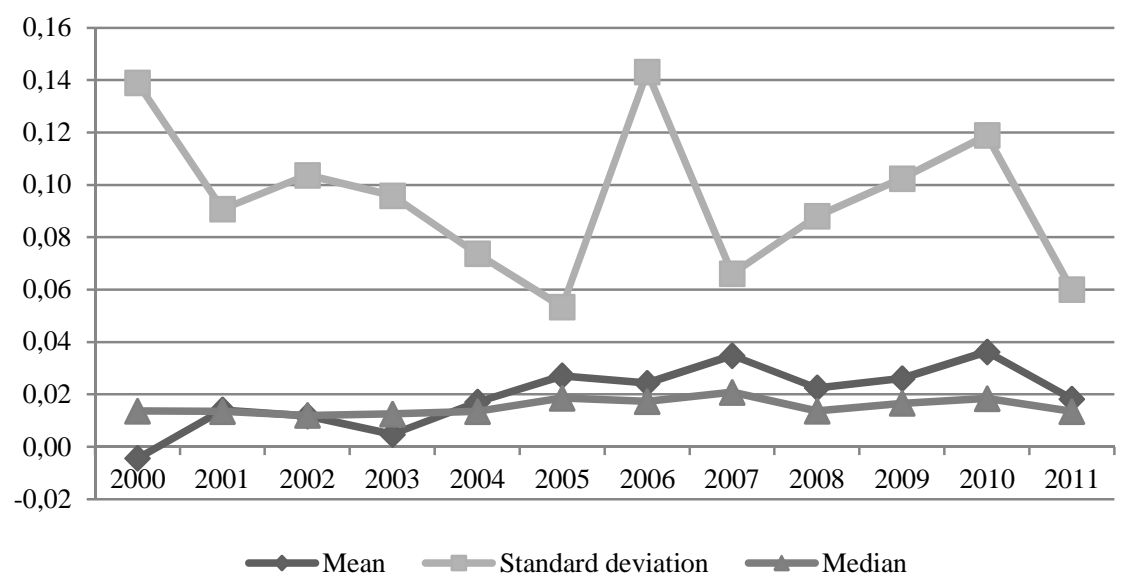

Source: own work. 
The average value of this ratio oscillates in the range of $-0.4 \%-3.6 \%$, while the median value is slightly lower and fluctuates around the $1.2 \%$ $2.1 \%$. It can be seen that the worst year for the industry was 2000 , the beginning of the study period, because then the average was $-0.4 \%$, it means that companies achieved a loss.

Table 12. The values of gross profitability of the selected sample

\begin{tabular}{|l|c|}
\hline Name of the bankrupt company & GP / SR \\
\hline BARTA & $-36,22$ \\
\hline KROTOSZYŃSKA SPÓŁDZIELNIA PRODUCENTÓW WOŁOWINY & 0,01 \\
\hline PMB Białystok S.A. & $-0,08$ \\
\hline RPM J. I P. GAWŁOWSKI S.C. & 0,02 \\
\hline SPÓŁDZIELNIA DOBROSŁAWA & $-0,02$ \\
\hline UBOJNIA DOBROSŁAWA SP. Z O.O. & $-0,12$ \\
\hline WIR EURO UBOJNIA & $-0,09$ \\
\hline $\begin{array}{l}\text { ZAKŁAD WĘDLINIARSKI MARYMUD MARIAN I RYSZARD } \\
\text { MUDZO }\end{array}$ & $-0,02$ \\
\hline ZM MAT CZERNIEWICE SP. Z O.O. & 0,01 \\
\hline ZPM IZABELA I ZBIGNIEW GRABOWSCY S.J. & $-0,01$ \\
\hline
\end{tabular}

Source: own work.

Analyzing the failed companies presented in Table 12, it can be seen that the seven companies are characterized by a negative value of the ratio. The companies are Barta, PMB, Spółdzielnia Dobrosława, Ubojnia, Wir, Zakład Wędliniarski oraz ZPM. This is considered as a negative phenomenon, because the company does not achieve sales effectiveness. The remaining companies are characterized by the values of ratio close to zero.

The last analyzed indicator is revenue growth rate (see Figure 11). The level of revenue growth ratio in companies which are in good financial condition usually increases (Mączyńska \& Zawadzki, 2006, p. 16). 
Figure 11. The values of revenue growth during 2000-2011

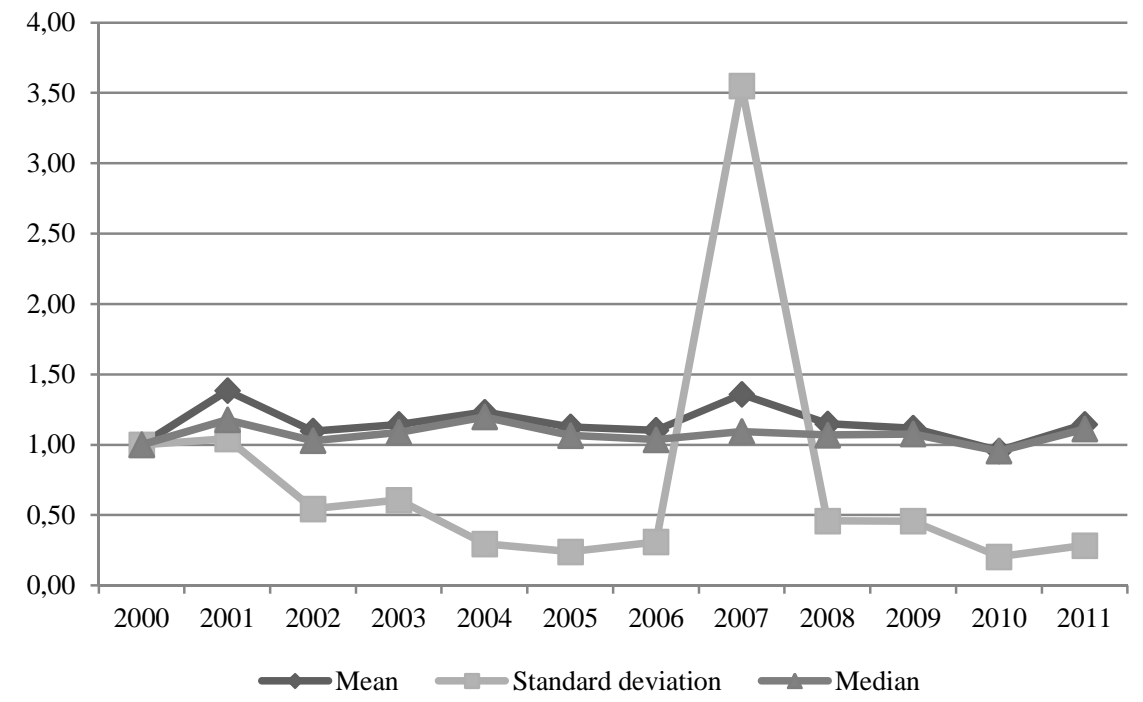

Source: own work.

Analyzing the eleventh and the last indicator, it can be stated that during the period companies increases sales by the average of $16 \%$ per year (average value fluctuates in the range of $-4 \%-38 \%$, this is a desirable trend that should occur in every company.

Table 13. The values of revenue growth of the selected sample

\begin{tabular}{|l|c|}
\hline Name of the bankrupt company & SR - SR \\
\hline BARTA & 0,98 \\
\hline $\begin{array}{l}\text { KROTOSZYŃSKA SPÓŁDZIELNIA PRODUCENTÓW } \\
\text { WOŁOWINY }\end{array}$ & 0,74 \\
\hline PMB Białystok S.A. & 0,50 \\
\hline RPM J. I P. GAWŁOWSKI S.C. & 0,69 \\
\hline SPÓŁDZIELNIA DOBROSŁAWA & 1,03 \\
\hline UBOJNIA DOBROSŁAWA SP. Z O.O. & 0,76 \\
\hline
\end{tabular}

Source: own work. 
Due to the lack of data the value of indicator was calculated only for six failed companies. In interpreting this table, we can conclude that only one failed company was characterized by the increase of the revenues for the year prior to bankruptcy. The declining value of revenues mean that companies do not prosper properly.

\section{Analysis of the results}

In Table 14 a summary of results - the causes of business failure in the sector - is presented.

Table 14. Possible causes of business failure based on the analysis of indicators

\begin{tabular}{|c|c|c|c|c|c|}
\hline \multirow[b]{2}{*}{ Name of the bankrupt company } & \multicolumn{5}{|c|}{ Causes of bankruptcy } \\
\hline & 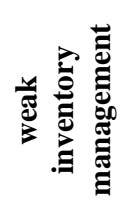 & 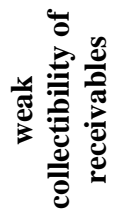 & 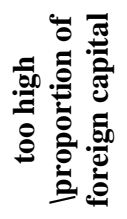 & 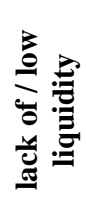 & 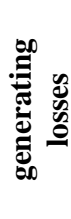 \\
\hline BARTA & $\mathrm{x}$ & $\mathrm{X}$ & & & $\mathrm{x}$ \\
\hline $\begin{array}{l}\text { KROTOSZYŃSKA SPÓŁDZIEL- } \\
\text { NIA PRODUCENTÓW WOŁOWI- } \\
\text { NY }\end{array}$ & & & $\mathrm{x}$ & & \\
\hline PMB Białystok S.A. & & & $\mathrm{x}$ & $\mathrm{x}$ & $\mathrm{x}$ \\
\hline RPM J. I P. GAWŁOWSKI S.C. & $\mathrm{x}$ & & $\mathrm{x}$ & $\mathrm{x}$ & \\
\hline SPÓŁDZIELNIA DOBROSŁAWA & & & & $\mathrm{x}$ & $\mathrm{x}$ \\
\hline $\begin{array}{l}\text { UBOJNIA DOBROSŁAWA SP. Z } \\
\text { O.O. }\end{array}$ & & & & $\mathrm{x}$ & $\mathrm{x}$ \\
\hline WIR EURO UBOJNIA & & $\mathrm{x}$ & $\mathrm{x}$ & $\mathrm{x}$ & $\mathrm{x}$ \\
\hline $\begin{array}{l}\text { ZAKŁAD WĘDLINIARSKI MA- } \\
\text { RYMUD MARIAN I RYSZARD } \\
\text { MUDZO }\end{array}$ & & $\mathrm{x}$ & & & $\mathrm{x}$ \\
\hline $\begin{array}{l}\text { ZM MAT CZERNIEWICE SP. Z } \\
\text { O.O. }\end{array}$ & $\mathrm{x}$ & & $\mathrm{x}$ & $\mathrm{x}$ & \\
\hline $\begin{array}{l}\text { ZPM IZABELA I ZBIGNIEW } \\
\text { GRABOWSCY S.J. }\end{array}$ & & & $\mathrm{x}$ & $\mathrm{X}$ & $\mathrm{x}$ \\
\hline
\end{tabular}

Source: own work. 
Analyzing the above table, it can be seen that one of the most common causes of business failure in the sector was generating losses of the core business, for which the company has been "brought to life". Seven out of ten companies did not generate profit.

Another reason was low or lack of liquidity. Only Barta and Zakład Wędliniaski were characterized by excess liquidity, which was caused by poor management of inventory and poor debt collection.

The next cause of bankruptcy is a too high share of foreign capital in the total assets. Generally, during the economic downturn the companies in which foreign capital was used to the largest extent have problems, resulting in excessive dependence on the lender, which translates into a high cost of foreign capital and higher financial risk. In this case, the rule is confirmed.

The next causes are improper and poor inventory management, as well as collectability of receivables - those causes affect a company's liquidity. In the analyzed sector proper turnover stocks is important. It is conditioned by a specific term of validity for consumption. Not using stock in the period of validity of generates costs. In the case of improper debt collection, it can also lead to bankruptcy, as the company sold products without receiving money for it at the right time.

\section{Conclusions}

In this study the sector animal slaughtering and processing in the period 2000-2011 was assessed. The basis for evaluation of the sector were the values of 13 commonly financial ratios used in discriminant analysis models. Financial reports of listed companies in the sector were used in paper - 395 company reports. The source of these financial reports are EMIS database. The results of the calculated ratios are presented in graphical form. The calculated mean values of selected indicators were used as a model to evaluate a sample bankrupt companies. The reasons for failure were assessed on the basis of appointed sample of companies. It should be noted that due to lack of access to the financial statements for the year prior to bankruptcy companies, the tested sample was 10 only companies.

Analysis of selected indicators showed that the standard values of indicators for the selected sector oscillate in the range (mean, median):

- 1,34-1,89 $(0,93-1,14)$ for the current liquidity ratio,

- 3,09-4,18 $(2,72-3,55)$ for the total asset turnover ratio,

- $43-57 \%$ (45-59\%) for the total debt ratio,

- $0,34-0,76(0,15-0,23)$ for net profit + depreciation to total liabilities, 
- 12-17 days (7-13 days) for the inventory turnover ratio,

- $6-13 \%$ (5-9\%) for the ratio return on investment (ROI),

- $38-50 \%$ (37-46\%) for equity to assets ratio,

- - (0.02) - $0.06(-(0.03)-0.06)$ for the size of the working capital ratio (1),

- $2-11 \%$ (3-6\%) for the ratio profitability on assets (ROA),

- 29-40 days (23-30 days) for receivables turnover ratio,

- - $(2 \%) 4 \%$ (1-2\%) for gross profitability ratio,

- 0,02-0,50 (- (0.04) -0.09) for the size of the working capital ratio (2),

- - (4\%) $36 \%$ (- (4\%) -20\%) for the revenue growth ratio.

Analyzing the calculated values of the indicators can be said that the industry is characterized by:

- a high return on capital employed, expressed in PLN, although there was a decline at the end of the period. At the end of the period, the value of indicator was 3.09, which means that $1 \mathrm{zl}$ involved capital in the company will bring $3.09 \mathrm{zl}$ revenue sales,

- reducing debt, which at the end of the period amounted to $43 \%$ of assets, which translates into a low financial risk,

- high degree of financial surplus of liability coverage, which reduces the time it takes the company to pay off liabilities. Especially during the economic recession the phenomenon is desired,

- quick inventory turnover, on average every 15 days followed stocks turnover. It is worth noting that it is very important to frequent turnover inventory in this sector, as it is usually food stocks, which have a validity term,

- high return on investment and a high return on assets to generate profits,

- low involvement of working capital to total assets,

- a moderate collectability of receivables, average of receivables collection period was 34 days, it is not a stunning result.

- Attempt to assess the causes of the bankruptcy of chosen sample based on selected indicators showed that:

- One of the most common causes of bankruptcy of companies in the sector is generating losses of the core business, for which the company is "brought to life" - 70\% of companies did not generate profits.

- The second reason was the low liquidity or lack of it.

- The third reason was too high share of foreign capital in total assets, because it leads to abnormal dependence on the lender.

- The fourth and fifth are caused by poor management of inventory and weak collectability of receivables, the causes which significantly affect liquidity. 
It is worth noting that the indicators: current ratio, equity to assets and return on investment (ROI) have predictive features. Studies have shown that even in this case, the values of these indicators are essential to the continued functioning of businesses.

The next step in the research is to analyze the companies due to the age and size of the company and increased research sample.

\section{References}

Altman E.I. (1993), Corporate Financial Distress and Bankruptcy. A Complete Guide to Predicting \& Avoiding and Distress and Profiting from Bankruptcy, John Wiley \& Sons, New York.

Altman E.I., Hotchkiss E. (2006), Corporate Financial Distress and Bankruptcy. Predict and Avoid Bankruptcy, Analyze and Invest in Distressed Debt, John Wiley \& Sons, New York.

Analiza finansowa $w$ zarzadzaniu wspótczesnym przedsiębiorstwem (2007), M. Walczak (ed.), Difin, Warsaw.

Appenzeller D., Szarzec K. (2004), Prognozowanie zagrożenia upadtościa polskich spótek publicznych, „Rynek Terminowy”, No. 1.

Ćwiąkała-Małys A., Nowak W. (2005), Zarys metodologiczny analizy finansowej, UWr, Wrocław.

Dudycz T., Hamrol M., Skoczylas W., Niemiec A. (2005), Finansowe wskaźniki sektorowe - pomoc przy analizie finansowej i ocenie zdolności przedsiębiorstwa do kontynuacji dziatalności, „Rachunkowość”, No. 3.

Ekonomiczne i prawne aspekty upadtości przedsiębiorstw (2007), B. Prusak (ed.), Difin, Warsaw.

Gajdka J., Stos, D. (1996a), Wykorzystanie analizy dyskryminacyjnej do badania przydatności przedsiębiorstwa na bankructwo [in:] Duraj J. (ed.), Przedsiębiorstwo na rynku kapitatowym, Konferencja Naukowa Łódź - Bukowina Tatrzańska, UŁ, Lodz.

Gajdka J., Stos D. (1996b), Wykorzystanie analizy dyskryminacyjnej w ocenie kondycji finansowej przedsiębiorstw, AE, Cracow.

Hadasik D. (1998), Upadtość przedsiębiorstw w Polsce i metody jej prognozowania, ,Zeszyty Naukowe, Seria II, AE, Poznań”, No. 153.

Hołda A., Micherda B. (2007), Kontynuacja działalności jednostki i modele ostrzegające przed upadłościq, Krajowa Izba Biegłych Rewidentów, Warsaw.

Hołda A. (2001), Prognozowanie bankructwa jednostki w warunkach gospodarki polskiej z wykorzystaniem funkcji dyskryminacyjnej Zh, „Rachunkowość”, No. 5.

Hamrol M., Czajka B., Piechocki M., (2004), Upadtość przedsiębiorstwa - model analizy dyskryminacyjnej, „Przegląd Organizacji”, No. 6.

Iwanicz-Drozdowska M. (2005), Zarzadzanie finansowe bankiem, PWE, Warsaw. 
Janek J., Żuchowski M. (2000), Analiza dyskryminacyjna i jej zastosowania wekonomii, Wydział Matematyki i Nauk Informacyjnych Politechniki Warszawskiej, Warsaw.

Korol T. (2010), Systemy ostrzegania przedsiębiorstw przed ryzykiem upadtości, Wolters Kluwer business, Warsaw.

Korol T., Prusak B. (2005), Upadtość przedsiębiorstw a wykorzystanie sztucznej inteligencji, $\mathrm{CeDeWu}$, Warsaw.

Kowalak R. (2008), Ocena kondycji finansowej przedsiębiorstwa, ODDK, Gdańsk.

Kowalczyk J., Kusak A. ( 2006), Decyzje finansowe firmy: Metody analizy, C H BECK, Warsaw.

Kusak A. (2006), Ptynność finansowa, Analiza i sterowanie, Wydanie rozszerzone i uzupełnione, WWZ, Warsaw.

Mączyńska E. (1994), Ocena kondycji przedsiębiorstwa, „Życie Gospodarcze”, No. 38.

Mączyńska E., Zawadzki M. (2006), Dyskryminacyjne modele predykcji bankructwa przedsiębiorstw, „Ekonomista”, No. 2.

Mohr A. (2006), Zarzadzanie finansami, co mówia liczby, Helion, Gliwice.

Pogodzińska M., Sojak S. (1995), Wykorzystanie analizy dyskryminacyjnej w przewidywaniu bankructwa przedsiębiorstw, „AUNC, Ekonomia”, Vol. XXV, No. 299.

Prusak B. (2005), Nowoczesne metody prognozowania zagrożenia finansowego przedsiębiorstw, Difin, Warsaw.

Skowrońska-Mielczarek A., Leszczyński Z. (2007), Controling- analiza i monitoring $w$ zarzadzaniu przedsiębiorstwem, Difin, Warsaw.

Tomczak S. (2012), Analiz pokazatelej, ispol'zuemyh v modeli prognozirovaniâ bankrotstva, Buhgalterskij učet, analiz, audit, nalogoobloženie i statistika: istoriâ razvitiâ ot drevnejših civilizacij do naših dnej: materialy I meždunarodnoj naučno-praktičeskoj konferencii, Rostov-na-Donu, edited by Ucenko L.N., Gončarova L.V., Rostov-na-Donu: Rostovskij gosudarstvennyj ekonomičeskij universitet.

Tomczak S. (2010), Wptyw kryzysu gospodarczego na kondycje finansowa spótek z sektora transportu publicznego, ,Zeszyty Naukowe Szkoły Głównej Gospodarstwa Wiejskiego w Warszawie. Ekonomika i Organizacja Gospodarki Żywnościowej”, No. 82.

Tomczak S. (2013), Analiza wskaźników finansowych w sektorze produkcji żywności w Polsce w okresie 2000-2011, „Zarządzanie i Finanse”, Vol. 11, No. 1, Part 2.

Tomczak S. (2009), Zintegrowana analiza finansowa na przyktadzie przedsiębiorstwa transportu publicznego, Człowiek - cywilizacja - przyszłość : VII Konferencja Naukowa Studentów, PWr, Wrocław.

Tomczak S., Górski A. (2012), Pokazateli, ispol'zuemye pri prognozirovanii bankrotstva, Bankrotstvo predpriâtij : problemy učeta i analiza : monografiâ edited by F. Franceviča Butynca, Žitomirskij gosudarstvennyj tehnologičeskij universitet, Žitomir. 
Tomczak S., Górski A. (2011), Influence of economic sector on predictability of financial indicators in discriminant analysis [in:] Zofia Wilimowska (ed.), Information systems architecture and technology: information as the intangible assets and company value source, $\mathrm{PWr}$, Wrocław.

Zaleska M. (2002), Identyfikacja ryzyka upadtości przedsiębiorstwa i banku, Difin, Warsaw.

Zaleska M. (2012), Ocena kondycji finansowej przedsiębiorstwa przez analityka bankowego, SGH, Warsaw. 